\title{
Characteristics of Nanocrystallite-CdS Produced by Low-Cost Electrochemical Technique for Thin Film Photovoltaic Application: The Influence of Deposition Voltage
}

\author{
Obi Kingsley Echendu, ${ }^{1,2}$ Francis Birhanu Dejene, ${ }^{1}$ Imyhamy Mudiy Dharmadasa, ${ }^{2}$ \\ and Francis Chukwuemeka Eze ${ }^{3}$ \\ ${ }^{1}$ Department of Physics, Qwa Qwa Campus, University of the Free State, X13, Phuthaditjhaba 9866, South Africa \\ ${ }^{2}$ Electronic Materials and Sensors Group, Materials and Engineering Research Institute, Sheffield Hallam University, \\ Sheffield S1 $1 \mathrm{WB}, \mathrm{UK}$ \\ ${ }^{3}$ Department of Physics, Federal University of Technology, PMB 1526, Owerri, Nigeria
}

Correspondence should be addressed to Obi Kingsley Echendu; oechendu@yahoo.com

Received 12 April 2017; Accepted 14 September 2017; Published 2 November 2017

Academic Editor: Prakash Basnyat

Copyright (C) 2017 Obi Kingsley Echendu et al. This is an open access article distributed under the Creative Commons Attribution License, which permits unrestricted use, distribution, and reproduction in any medium, provided the original work is properly cited.

\begin{abstract}
Electrochemical deposition and characterization of nanocrystallite-CdS thin films for thin film solar cell application are reported. The two-electrode system used provides a relatively simple and cost-effective approach for large-scale deposition of semiconductors for solar cell and other optoelectronic device application. Five CdS thin films were deposited for 45 minutes each at different cathodic deposition voltages in order to study their properties. X-ray diffraction study reveals that the as-deposited films contain mixed phases of hexagonal and cubic CdS crystallites with large amounts of internal strain and dislocation density. Postdeposition annealing results in phase transformation which leaves the films with only the hexagonal crystal phase and reduced strain and dislocation density while increasing the crystallite sizes from $21.0-42.0 \mathrm{~nm}$ to $31.2-63.0 \mathrm{~nm}$. Photoelectrochemical cell study shows that all the CdS films have n-type electrical conductivity. Optical characterization reveals that all samples show similar transmittance and absorbance responses with the transmittance slightly increasing towards higher growth voltages. All the annealed films show energy bandgap of $2.42 \mathrm{eV}$. Scanning electron microscopy and energy dispersive X-ray analyses show that grains on the surface of the films tend to get cemented together after annealing with prior $\mathrm{CdCl}_{2}$ treatment while all the films are S-rich.
\end{abstract}

\section{Introduction}

CdS is a wide bandgap II-VI compound semiconductor with a direct bulk bandgap of $2.42 \mathrm{eV}$ [1]. Due to its desirable properties, it finds use in photovoltaic solar cells $[2,3]$, piezo transducers [4], photoresistors, luminescence devices [5], Schottky diodes and metal-semiconductor field effect transistors (MESFETs) [6], heterojunction diodes [7], insulated gate thin film transistors [8], and gas sensors [9]. It is also used in microelectronics, nonlinear optics, catalysis, photoelectrochemistry [10], and in photodetectors [11]. In its application in photovoltaics, CdS has been used as an n-type heterojunction partner to $\mathrm{CdTe}, \mathrm{CuS}$, and $\mathrm{Cu}(\mathrm{In}, \mathrm{Ga}) \mathrm{Se}_{2}$ (CIGS) absorber materials for the fabrication of CdS/CdTe, CdS/ $\mathrm{CuS}$, and CdS/CIGS solar cells [12-14].

Several growth techniques have been used for the deposition of CdS for various uses. These techniques include chemical bath deposition (CBD) [15], vacuum evaporation, chemical vapour deposition [16], spray pyrolysis [17], sputtering [18], screen printing [19], sol-gel [20], close space sublimation (CSS) [21], and electrodeposition (ED) [22]. As is common in most electrodeposition processes for semiconductors in the past, electrodeposition of CdS has always been reported in the literature based on the conventional threeelectrode configuration [23]. Report on the use of twoelectrode system for the electrodeposition of CdS is very 
scarce in the literature, and one can only find two major reports to date $[22,24]$. Diso et al. [22] grew their CdS materials using $\mathrm{CdCl}_{2}$ and $\mathrm{Na}_{2} \mathrm{~S}_{2} \mathrm{O}_{3}$ as precursors but at a $\mathrm{pH}$ of 1.4 and temperature of $45^{\circ} \mathrm{C}$ for fear of precipitation. Both their reported as-deposited and heat-treated CdS films had hexagonal crystal structure without any phase transformation as a result of postdeposition heat treatment. Abdul-Manaf et al. [24] on the other hand used $\mathrm{CdCl}_{2}$ and $\left(\mathrm{NH}_{4}\right)_{2} \mathrm{~S}_{2} \mathrm{O}_{3}$ as precursors but grew $\mathrm{CdS}$ at a $\mathrm{pH}$ of 2.0 and a temperature of $85^{\circ} \mathrm{C}$. The as-deposited CdS materials in this case had a mixture of hexagonal CdS, cubic CdS, and orthorhombic sulphur crystal phases which transformed to purely hexagonal phase after postgrowth heat treatment. Both Diso et al. and Abdul-Manaf et al. did not report the postdeposition heat treatment with prior $\mathrm{CdCl}_{2}$ treatment. Again, both groups did not report morphological characterization of CdS films grown at different growth voltages but only reported the morphological characterization of CdS grown at a particular voltage and annealed under different temperature conditions.

Under the low temperature $\left(45^{\circ} \mathrm{C}\right)$ and low $\mathrm{pH}(1.4)$ used by Diso et al., they did not observe mixed phases of CdS. It is also noted that these temperature and $\mathrm{pH}$ are substantially far away from those $\left(>80^{\circ} \mathrm{C}\right.$ and $\sim 2.00$, resp.) under which $\mathrm{CdTe}$ is usually grown for $\mathrm{CdS} / \mathrm{CdTe}$ solar cell fabrication $[2,25]$. However, Abdul-Manaf et al. who grew CdS at relatively higher temperature of $85^{\circ} \mathrm{C}$ and $\mathrm{pH}$ of 2.00 reported the presence of mixed cubic and hexagonal phases of $\mathrm{CdS}$ with the presence of orthorhombic sulphur all in their asdeposited CdS materials. These mixed phases transformed to purely hexagonal phase after postgrowth heat treatment.

Then, in order to see whether the presence of these mixed phases is a function of growth temperature and $\mathrm{pH}$ or a function of the sulphur precursor, authors decided to grow $\mathrm{CdS}$ in the present work at a temperature of $80^{\circ} \mathrm{C}$ and $\mathrm{pH}$ of 1.80 , both of which are in-between the values used by Diso et al. and Abdul-Manaf et al. These growth parameter values are still very close to those for the growth of CdTe on CdS for solar cell fabrication. We have also used $\mathrm{Na}_{2} \mathrm{~S}_{2} \mathrm{O}_{3}$ as the sulphur precursor since Abdul-Manaf et al. have observed mixed phases with $\left(\mathrm{NH}_{4}\right)_{2} \mathrm{~S}_{2} \mathrm{O}_{3}$ as sulphur precursor. In the present work, $\mathrm{CdCl}_{2}$ and $\mathrm{Na}_{2} \mathrm{~S}_{2} \mathrm{O}_{3}$ have been used as precursors and the $\mathrm{CdS}$ materials were grown at a $\mathrm{pH}$ of 1.8 and temperature of $80^{\circ} \mathrm{C}$.

The major reasons for the use of two-electrode system include the following: (i) to prevent any possible contamination of the deposition electrolyte by ions such as $\mathrm{Ag}^{+}$and $\mathrm{K}^{+}$ which may eventually leak into the deposition electrolyte from the porous wick of the commonly used $\mathrm{Ag} / \mathrm{AgCl}$ and $\mathrm{Hg} / \mathrm{HgCl}$ (saturated calomel electrode (SCE)) reference electrodes during the electrodeposition process at elevated temperatures and (ii) to reduce the cost due to reference electrode, as reported in recent publications by the main author's research group [26, 27].

In the fabrication of high-efficiency solar cells using CdS as window material, the most commonly used technique for the deposition of CdS is CBD [2] while CdTe is deposited using CSS [2], sputtering [18], or electrodeposition [28]. Due to the nature of the $\mathrm{CBD}$ as a batch process, lots of
Cd-containing wastes are generated in the large-scale deposition of CdS for solar cell fabrication. This no doubt raises environmental concerns and costs a huge sum of money for waste management and disposal. In an industrial production line, this situation, coupled with the use of at least two different deposition techniques, presents real issues and leads to the production of expensive solar panels. It is preferable in such an industrial process to have only one production line by using only one technique to deposit both $\mathrm{CdS}$ and CdTe. A continuous process such as electrodeposition fits into this one production line that can be used for the production of less expensive solar panels.

One major factor in electrodeposition of semiconductors is the choice of the right deposition voltage as this, in most cases, affects the properties of the deposited materials. For example, the stoichiometry and therefore the electrical conductivity type of some compound semiconductors like CdTe are affected by the deposition voltage used [29]. It is for these reasons that the effect of deposition voltage on electrodeposited CdS thin films using two-electrode system has been studied and reported in this work. There is yet another major reason why the development of electrodeposited CdS material is important for the fabrication of allelectrodeposited solar cells employing $\mathrm{CdS}$ as window or buffer layer. CBD-grown CdS is usually deposited at very high $\mathrm{pH}$ values in the range of 9 and above [1] whereas electrodeposited $\mathrm{CdTe}$ is grown at low $\mathrm{pH}$ values in the range of 1-2 [27-29]. Experience has shown that immersing the CBD-CdS grown in alkaline environment into the acidic $\mathrm{CdTe}$ electrodeposition electrolyte could sometimes result in the peeling off of the CBD-CdS due to the sharp difference in $\mathrm{pH}$ of the deposition environments of the two materials. To solve this problem, the electrodeposition of CdS reported in the present work has been carried out at a $\mathrm{pH}$ of $1.8 \pm 0.02$ close to $2.0 \pm 0.02$ for CdTe deposition to bridge the $\mathrm{pH}$ gap between the deposition of $\mathrm{CdS}$ and CdTe.

\section{Materials and Methods}

2.1. Preparation of CdS Deposition Electrolyte. The CdS deposition electrolyte was prepared using $0.3 \mathrm{M} \mathrm{CdCl}_{2} \cdot \mathrm{H}_{2} \mathrm{O}$ and $0.03 \mathrm{M} \mathrm{Na}_{2} \mathrm{~S}_{2} \mathrm{O}_{3} \cdot 5 \mathrm{H}_{2} \mathrm{O}$ in $800 \mathrm{ml}$ of de-ionised water. Both chemicals were of laboratory reagent grade and purchased from Fisher Scientific, United Kingdom. The resulting electrolyte is contained in a $1000 \mathrm{ml}$ plastic beaker. The solution containing only $\mathrm{CdCl}_{2} \cdot \mathrm{H}_{2} \mathrm{O}$ was first prepared. The $\mathrm{pH}$ was adjusted to $1.80 \pm 0.02$ at room temperature using $\mathrm{HCl}$ and $\mathrm{NH}_{4} \mathrm{OH}$ as the case may be. The $1000 \mathrm{ml}$ plastic beaker containing this solution was put inside a $2000 \mathrm{ml}$ glass beaker containing some de-ionised water. This serves as a water bath to ensure uniform heating of the solution. The entire container was placed on a hot plate with a magnetic stirrer. After stirring the $\mathrm{CdCl}_{2} \cdot \mathrm{H}_{2} \mathrm{O}$ solution moderately at 400 rotation per minute (r.p.m) for 24 hours, it was heated to a temperature of $80 \pm 2^{\circ} \mathrm{C}$ and a cyclic voltammetry was carried out in two-electrode configuration using glass coated with fluorine-doped thin oxide (glass/FTO) as the working electrode (cathode) and high-purity carbon rod as the anode (counter electrode). From the resulting voltammogram, the 


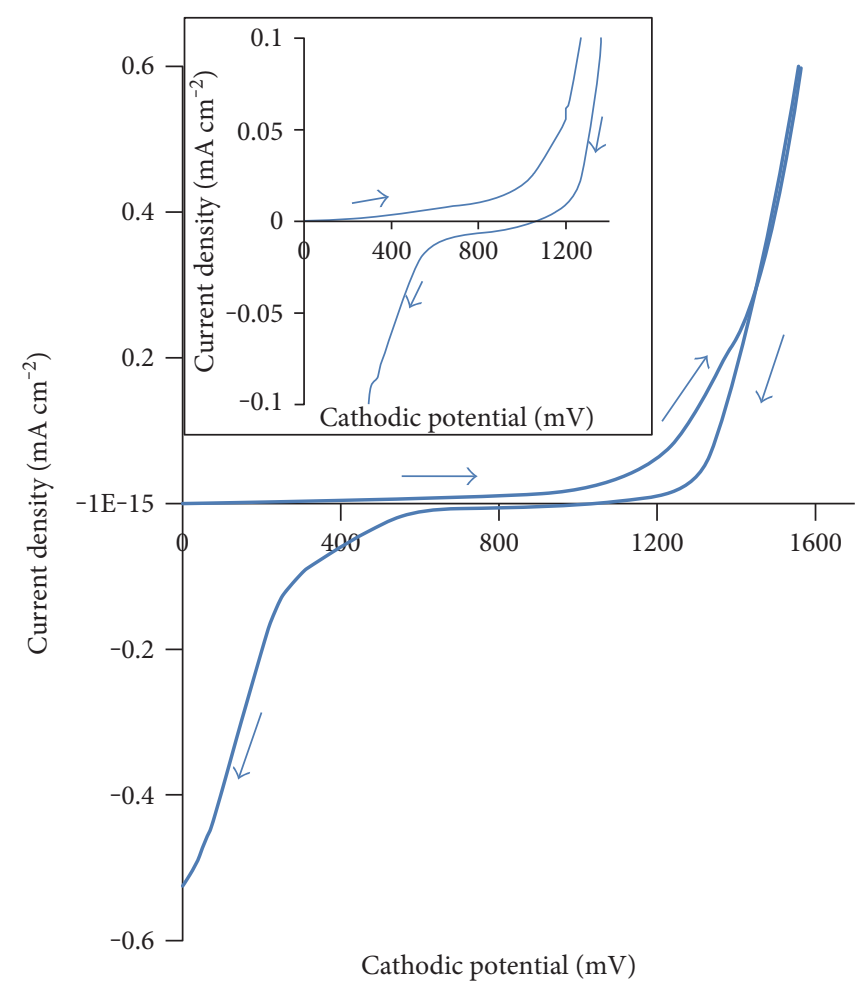

Figure 1: Two-electrode cyclic voltammogram of CdS deposition electrolyte containing $0.3 \mathrm{M} \mathrm{CdCl}_{2}+0.03 \mathrm{M} \mathrm{Na}_{2} \mathrm{~S}_{2} \mathrm{O}_{3}$ at a pH of $1.80 \pm 0.02$ and temperature of $80 \pm 2^{\circ} \mathrm{C}$. (Inset shows expansion of the potential axis for clarity.)

deposition voltage of $\mathrm{Cd}$ was identified. Slightly below this voltage, the $\mathrm{CdCl}_{2} \cdot \mathrm{H}_{2} \mathrm{O}$ solution was then subjected to electro-purification for $48 \mathrm{hrs}$ to remove any metallic impurities in the $\mathrm{CdCl}_{2} \cdot \mathrm{H}_{2} \mathrm{O}$ before the addition of $\mathrm{Na}_{2} \mathrm{~S}_{2} \mathrm{O}_{3} \cdot 5 \mathrm{H}_{2} \mathrm{O}$. The $\mathrm{pH}$ of the resulting electrolyte was then adjusted again to $1.80 \pm 0.02$ at room temperature.

2.2. Substrate Preparation. The substrates used for the electrodeposition of CdS were glass/FTO which were prepared by cutting them into sizes of $3.0 \mathrm{~cm} \times 2.0 \mathrm{~cm} \times 3.0 \mathrm{~mm}$ followed by cleaning with soap solution in an ultrasonic bath for 15 minutes. This was also followed by cleaning with acetone and methanol using cotton buds. The substrates were then rinsed with de-ionised water and dried in a stream of $\mathrm{N}_{2}$.

2.3. Electrodeposition of CdS. After preparing the CdS deposition electrolyte, a cyclic voltammogram of the electrolyte was recorded using a computerised Gill AC potentiostat (ACM Instruments, Cumbria, UK) in two-electrode configuration at a temperature of $80 \pm 2^{\circ} \mathrm{C}$ with a stirring rate in the neighbourhood of 400 r.p.m using glass/FTO as the substrate. The cyclic voltammogram is shown in Figure 1.

The possible range of cathodic deposition voltages for CdS was obtained from the voltammogram to be 1300$1500 \mathrm{mV}$. Now, the reduction of $\mathrm{S}_{2} \mathrm{O}_{3}{ }^{2-}$ ions takes place earlier at a lower cathodic potential than the reduction of $\mathrm{Cd}^{2+}$ ions which happens at a relatively higher cathodic potential [30]. The proposed equation of reduction of $\mathrm{S}_{2} \mathrm{O}_{3}{ }^{2-}$ in the acidic solution is therefore given by

$$
\mathrm{S}_{2} \mathrm{O}_{3}^{2-}+6 \mathrm{H}^{+}+6 \mathrm{e}^{-}=3 \mathrm{H}_{2} \mathrm{O}+\mathrm{S}^{2-}+\mathrm{S}
$$

In the presence of $\mathrm{Cd}^{2+}$ in the solution, the overall reaction for the formation of $\mathrm{CdS}$ at the cathode is therefore given by

$$
\mathrm{Cd}^{2+}+\mathrm{S}_{2} \mathrm{O}_{3}^{2-}+6 \mathrm{H}^{+}+6 \mathrm{e}^{-}=3 \mathrm{H}_{2} \mathrm{O}+\mathrm{CdS}+\mathrm{S} .
$$

The presence of colloidal sulphur as observed in (1) and (2) turns the solution muddy with time. The rate at which this happens however depends on the concentration of the $\mathrm{S}_{2} \mathrm{O}_{3}{ }^{2-}$ in the solution. For this reason, the concentration of $\mathrm{Na}_{2} \mathrm{~S}_{2} \mathrm{O}_{3}$ is kept very low compared to that of $\mathrm{CdCl}_{2}$.

Five CdS layers were deposited on glass/FTO within the above identified voltage range for 45 minutes each and at intervals of $5 \mathrm{mV}$. By controlling the stirring rate of the deposition electrolyte and gradually adding $\mathrm{Na}_{2} \mathrm{~S}_{2} \mathrm{O}_{3}$ to the deposition electrolyte, the deposition current density $J$ was maintained at an average value of $246.6 \mu \mathrm{Acm}^{-2}$ for each sample for the duration of the deposition.

It is important to state that the thickness and uniformity of electrodeposited semiconductors are easily controlled by controlling the deposition parameters such as deposition current density, stirring rate, temperature, $\mathrm{pH}$, and concentration of ions in the deposition electrolyte. Increasing the stirring rate increases the deposition current density and therefore the thickness of the deposited film. However, if the stirring rate and therefore the current density are very high, rapid deposition of the film takes place but with poor uniformity. Therefore for a uniform deposition, moderate 
stirring rate and current density are desirable. From authors' experience, the stirring rate in the neighbourhood of 400 r.p.m and current density of $200-300 \mu \mathrm{Acm}^{-2}$ for CdS produce very uniform layers. Again, increasing the deposition temperature and concentration of ions in the electrolyte increases the deposition current density and therefore the deposition rate. However, for better films with good uniformity, these parameters must be moderate. Deposition rate also varies with $\mathrm{pH}$ in such a way that very high and very low $\mathrm{pH}$ values do not produce films with good uniformity and stoichiometry. Moderate $\mathrm{pH}$ values are therefore necessary for good uniform films. The deposition parameters used in this work have been chosen from experience after some cycles of deposition. After deposition, each sample was divided into two equal parts. One set of the parts was designated as-deposited samples. For the other set, the samples were dipped in a saturated solution of $\mathrm{CdCl}_{2}$ in methanol. The samples were allowed to dry in air and then annealed in air at $400^{\circ} \mathrm{C}$ for 20 minutes before characterising them. The reason for dipping the samples in $\mathrm{CdCl}_{2}$ solution before annealing is to see the effect of the $\mathrm{CdCl}_{2}$ treatment on CdS films. It can be recalled that $\mathrm{CdCl}_{2}$ treatment is a wellknown important step in the fabrication of CdTe-based solar cells, in which the treatment is usually done on CdS/CdTe stack before back metal contact fabrication. Both the asdeposited and annealed CdS samples were characterised in order to study the effect of the various selected cathodic deposition voltages on the electrical, structural, optical, morphological, and compositional properties of the electrodeposited CdS films for application in thin film solar cells.

2.4. Characterisation of the Deposited CdS Films. The selected techniques employed in this study for the electrical, structural, optical, morphological, and compositional characterisation of the electrodeposited CdS thin films, respectively, include photoelectrochemical (PEC) cell using a digital voltmeter, light source, and $0.1 \mathrm{M} \mathrm{Na}_{2} \mathrm{~S}_{2} \mathrm{O}_{3}$ electrolyte as reported previously [26]; X-ray diffraction (XRD) using Philips X'Pert Pro diffractometer (Philips Analytical, Almelo, The Netherlands) with $\mathrm{Cu}-\mathrm{K} \alpha$ excitation wavelength of $1.5406 \AA$; optical absorption using Cary 50 UV-VIS spectrophotometer (Varian Instrument, Australia); scanning electron microscopy (SEM) using FEG NOVA NANO SEM equipment (FEI company, The Netherland); and energy dispersive X-ray (EDX) using EDX detector attached to the SEM machine. The thickness $T$ of each sample was determined using the Faraday formula [26].

$$
T=\frac{M J t}{n F \rho},
$$

where $M$ is the molar mass of $\mathrm{CdS}, J$ is the average deposition current density, $t$ is growth time, $n$ is the number of electrons transferred in the formation of $\mathrm{CdS}$, and $\rho$ is the density of CdS.

Since the deposition time and the deposition current density were the same for the growth of each sample, all five samples have equal thickness of about $516 \mathrm{~nm}$. This is to ensure that the only variable during the deposition of the samples is the cathodic growth voltage $V_{\mathrm{g}}$. The crystallite sizes of the samples were estimated using the Scherer equation in (4) as reported recently in [31].

$$
D=\frac{0.94 \lambda}{\beta \cos \theta},
$$

where $D$ is the crystallite size, $\lambda$ is the wavelength of the $\mathrm{X}$-ray, and $\beta$ is the full width at half maximum (FWHM) of the XRD peak with which the crystallite size is calculated and $\theta$ is the corresponding Bragg angle.

The internal strain, $\varepsilon$, which is the distortion in the crystallites as a result of tensile or compressive stress is obtained for the films using (5) as reported in [32].

$$
\varepsilon=\frac{\beta}{4 \tan \theta} .
$$

The dislocation density, $\delta$, which is the length of dislocation lines per unit volume of crystal in each sample, is estimated using the Williamson-Smallman relation given by (6) as reported in [33].

$$
\delta=\frac{1}{D^{2}}
$$

The number of crystallites per unit area of each sample, $N$, was obtained using the expression in (7) as reported in [32].

$$
N=\frac{t}{D^{3}}
$$

where $t$ is the thickness of the film.

Equations (4), (5), (6), and (7) were used for the structural characterisation of the films. Optical characterisation of the samples was done using absorbance and transmittance measurements. From the graph of the square of absorbance versus photon energy, the energy bandgaps of the materials were estimated by extrapolating the straight-line portion of the graph to the photon energy axis. This is a very quick and easy way of estimating the energy bandgaps of semiconductors without actually determining the absorption coefficient and doing the Tauc plot.

\section{Results and Discussion}

3.1. Structural Characterisation Using X-Ray Diffraction Measurements. Figures 2(a) and 2(b) show the XRD patterns of CdS layers deposited for 45 minutes each at a temperature of $80 \pm 2^{\circ} \mathrm{C}$ and at different cathodic voltages. The five layers were grown at cathodic voltages from $1445 \mathrm{mV}$ to $1465 \mathrm{mV}$ at $5 \mathrm{mV}$ intervals. All as-deposited samples in Figure 2(a) show a characteristic polycrystalline feature with mixed hexagonal and cubic crystalline phases. There are four peaks corresponding to the hexagonal phase with (100), (002), (101), and (110) orientations and two peaks corresponding to the (111) and (200) cubic phase. The hexagonal phase peaks match the reference Joint Committee on Powder Diffractions and Standards (JCPDS) file number 01-075-1545 for hexagonal CdS while the cubic phase peaks match the reference file number 01-080-0019 for cubic CdS. In the five samples, the 


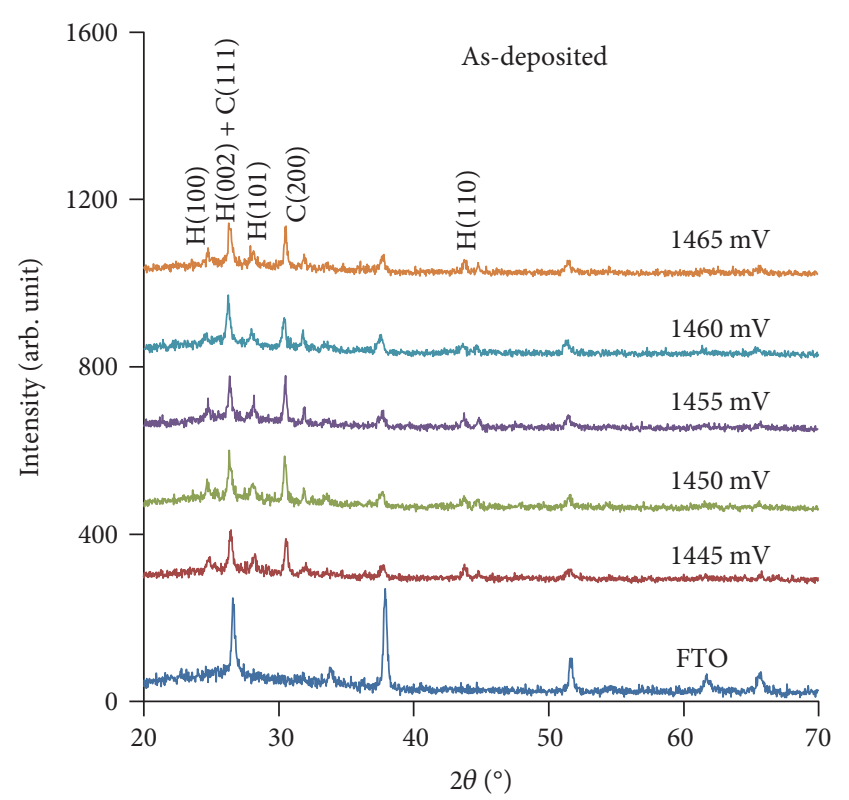

(a)

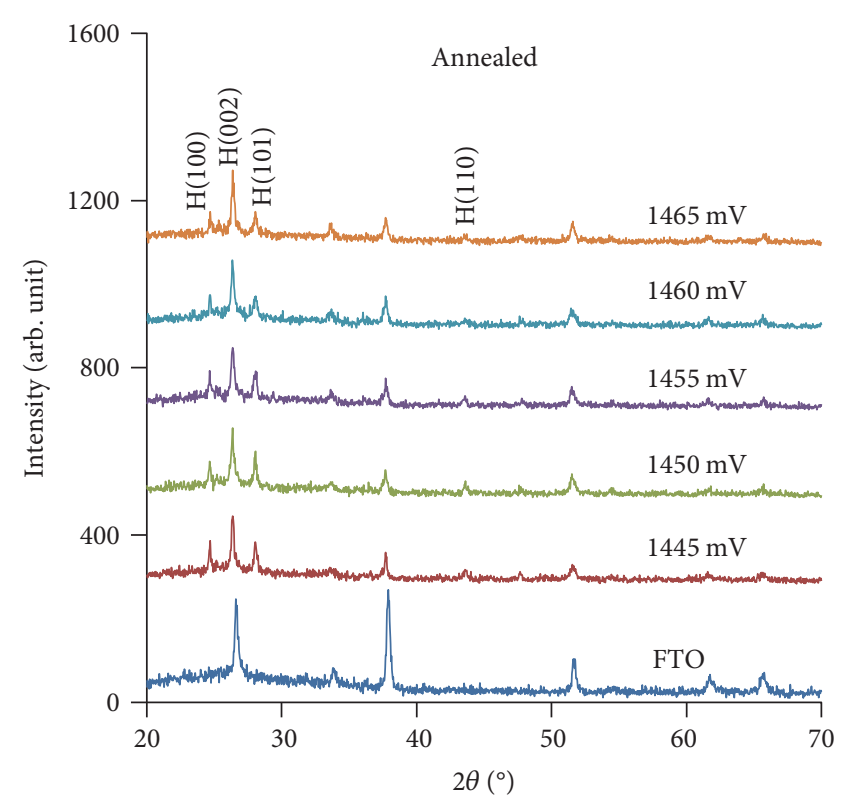

(b)

FIGURE 2: XRD patterns of (a) as-deposited and (b) annealed CdS layers deposited for 45 minutes at different cathodic growth voltages.

(100) peaks occur at $2 \theta$ values in the range $24.7-24.9^{\circ}$, the (002) peaks at $2 \theta$ values in the range $26.3-26.5^{\circ}$, the (101) peaks at $2 \theta$ values in the range $27.9-28.2^{\circ}$, and the (110) peaks at $2 \theta$ values in the range $43.6-43.7^{\circ}$. Similarly, the cubic (111) peaks occur at $2 \theta$ values in the range $26.3-26.4^{\circ}$ and the (200) peaks occur at $2 \theta$ in the range $30.4-30.5^{\circ}$.

These observed mixed phases of cubic and hexagonal $\mathrm{CdS}$ in the as-deposited CdS materials grown at the different voltages are similar to those observed by Abdul-Manaf et al., who also observed the presence of elemental sulphur in addition. However, elemental sulphur has not been observed in our XRD results of the present work as against the observation of Abdul-Manaf et al. These results therefore suggest that the incidence of mixed phases in as-deposited CdS is not necessarily caused by the nature of sulphur precursor but rather it has to do with the growth conditions such as temperature and $\mathrm{pH}$.

After $\mathrm{CdCl}_{2}$ treatment and annealing in air at $400^{\circ} \mathrm{C}$ for 20 minutes, a startling observation was made. This was the disappearance of the peaks representing the cubic phase of CdS. Figure 2(b) shows the XRD patterns of the annealed CdS layers with only peaks for the hexagonal phase. Metin et al. [34] reported a similar scenario of mixed cubic and hexagonal phases in CBD-CdS in which the cubic phase disappeared after annealing. A slight narrowing of the range of $2 \theta$ values for the four hexagonal phase peaks was also observed with all the (100) peaks occurring at a $2 \theta$ value of $24.7^{\circ}$, all the (002) peaks occurring at a $2 \theta$ value of $26.4^{\circ}$, the (101) peaks occurring at $2 \theta$ range of $28.0-28.1^{\circ}$, and the (110) peaks occurring at $2 \theta$ range of $43.5-43.6^{\circ}$.

Figure 2(b) also shows that the preferred orientation of the crystallites in the hexagonal CdS phase is in the (002) crystal plane. The disappearance of the peaks corresponding to the cubic phase after annealing suggests that the cubic phase of CdS is not stable, at least, at the annealing temperature used in this work. An estimation of the crystallite sizes of the layers was done using the Scherrer formula in (3), and the effect of annealing on them was investigated for the five samples. In doing this however, only the hexagonal phase is considered since the cubic phase is not stable on annealing. The (002) peak was considered as the preferred orientation for these samples. Although the (002) peak coincides with FTO peak, a close look at this peak in comparison with the highest FTO peak (at $2 \theta, \sim 37^{\circ}$ ) in the XRD patterns of the five samples shows that the (002) peak actually represents the preferred orientation of CdS crystallites in the layers. However, for crystallite size estimation, the (101) peaks were used for two reasons. First, the (002) peaks coincide with FTO peak which will likely introduce error in the result of the crystallite size estimation. Secondly, the (101) peaks are the next in intensity to the (002) peaks.

Tables 1 and 2 show the results of analysis of the (101) peak for as-deposited and annealed CdS layers, respectively. Using the JCPDS file number 01-075-1545 for hexagonal CdS phase $\left(2 \theta=28.2^{\circ}\right.$, interplanar spacing $d=3.1648 \AA$ and relative intensity $=100 \%$ ) for the (101) peak) as a reference, Tables 1 and 2 show that all the as-deposited and annealed samples displayed a slight downward shift in the $2 \theta$ values and a slight upward shift in the $d$-spacing relative to the reference material.

In terms of the FWHM, all samples experienced increase in crystallite sizes after annealing, with the samples grown at $1445 \mathrm{mV}$ and $1450 \mathrm{mV}$ showing the highest crystallite size of $63.02 \mathrm{~nm}$. However, in terms of the crystallite sizes after annealing, $1450 \mathrm{mV}$ produces the highest percentage increase in crystallite size of $\sim 200 \%$.

The observed shift in $2 \theta$ positions and values of $d$-spacing from those of the standard reference material suggests that the deposited CdS films are strained. The increase in $d$-spacing values and decrease in $2 \theta$ values from the standard values 
TABLE 1: XRD analysis of the (101) hexagonal peak for as-deposited CdS thin films grown at different cathodic voltages.

\begin{tabular}{lccccc}
\hline $\begin{array}{l}\text { Cathodic growth } \\
\text { voltage, } V_{\mathrm{g}}(\mathrm{mV})\end{array}$ & Growth time, $t(\mathrm{~min})$ & $2 \theta\left(^{\circ}\right)$ & FWHM, $\beta\left(^{\circ}\right)$ & $d$-spacing, $d(\AA)$ & Crystallite size, $D(\mathrm{~nm})$ \\
\hline 1445 & 45 & 28.2 & 0.3247 & 3.1658 & 25.22 \\
1450 & 45 & 28.1 & 0.3897 & 3.1752 & 21.01 \\
1455 & 45 & 28.1 & 0.3897 & 3.1768 & 21.01 \\
1460 & 45 & 28.0 & 0.3897 & 3.1873 & 21.01 \\
1465 & 45 & 28.1 & 0.3897 & 3.1704 & 21.01 \\
\hline
\end{tabular}

TABLE 2: XRD analysis of the (101) hexagonal peak for annealed CdS thin films deposited at different cathodic voltages.

\begin{tabular}{lccccc}
\hline $\begin{array}{l}\text { Cathodic growth } \\
\text { voltage, } V_{\mathrm{g}}(\mathrm{mV})\end{array}$ & Growth time, $t(\mathrm{~min})$ & $2 \theta\left(^{\circ}\right)$ & FWHM, $\beta\left(^{\circ}\right)$ & $d$-spacing, $d(\AA)$ & Crystallite size, $D(\mathrm{~nm})$ \\
\hline 1445 & 45 & 28.0 & 0.1299 & 3.1840 & 63.02 \\
1450 & 45 & 28.0 & 0.1299 & 3.1855 & 63.02 \\
1455 & 45 & 28.0 & 0.2598 & 3.1818 & 31.51 \\
1460 & 45 & 28.1 & 0.2598 & 3.1792 & 31.51 \\
1465 & 45 & 28.1 & 0.2598 & 3.1803 & 31.51 \\
\hline
\end{tabular}

TABLE 3: Evaluation of strain and dislocation density of the CdS films deposited at different cathodic voltages.

\begin{tabular}{|c|c|c|c|c|c|c|c|c|c|}
\hline \multirow[b]{2}{*}{$V_{\mathrm{g}}(\mathrm{mV})$} & \multicolumn{3}{|c|}{ As-deposited } & \multicolumn{3}{|c|}{ Annealed } & \multicolumn{3}{|c|}{ Comparison } \\
\hline & $\varepsilon_{1} \times 10^{-3}$ & $\begin{array}{c}\delta_{1} \times 10^{11} \\
\left(\text { lines } / \mathrm{cm}^{2}\right)\end{array}$ & $\begin{array}{c}N_{1} \times 10^{12} \\
\left(\mathrm{~cm}^{-2}\right)\end{array}$ & $\varepsilon_{2} \times 10^{-3}$ & $\begin{array}{c}\delta_{2} \times 10^{11} \\
\left(\text { lines } / \mathrm{cm}^{2}\right)\end{array}$ & $\begin{array}{c}N_{2} \times 10^{12} \\
\left(\mathrm{~cm}^{-2}\right)\end{array}$ & $\varepsilon_{1} / \varepsilon_{2}$ & $\delta_{1} / \delta_{2}$ & $N_{1} / N_{2}$ \\
\hline 1445 & 5.64 & 1.57 & 3.2 & 2.68 & 0.25 & 0.2 & 2.10 & 6.28 & 16.0 \\
\hline 1450 & 6.79 & 2.27 & 5.6 & 2.68 & 0.25 & 0.2 & 2.53 & 9.08 & 28.0 \\
\hline 1455 & 6.79 & 2.27 & 5.6 & 4.54 & 1.01 & 1.6 & 1.50 & 2.25 & 3.5 \\
\hline 1460 & 6.82 & 2.27 & 5.6 & 4.53 & 1.01 & 1.6 & 1.51 & 2.25 & 3.5 \\
\hline 1465 & 6.79 & 2.27 & 5.6 & 4.53 & 1.01 & 1.6 & 1.50 & 2.25 & 3.5 \\
\hline
\end{tabular}

indicate that there is inhomogeneous tensile stress on the crystallites of these films which induces strain in the crystallites. This also suggests the presence of defects such as dislocation, vacancies, or interstitials. However, for the electrodeposited CdS films under study, the influence of FWHM on the strain, dislocation density, and number of crystallites per unit area overrides those of $2 \theta$ and $d$-spacing. As a result, the annealed samples show reduced internal strain, dislocation density, and number of crystallites per unit area following (5), (6), and (7), as shown in Table 3, irrespective of the downward shift in $2 \theta$ and increase in $d$-spacing. This is a major advantage of postdeposition annealing in which case there is recrystallisation leading to release of stress and growth in crystallite size as a result of coalescence of smaller crystallites. Table 3 and Figures 3(a) and 3(b) show the results of evaluation of internal strain $\varepsilon$, dislocation density $\delta$, and number of crystallites per unit area $N$ for the as-deposited and annealed CdS samples.

After annealing, there is an overall reduction in the amount of strain and dislocation lines in the CdS samples as observed in Table 3 and Figures 3(a) and 3(b). The internal strain and dislocation density slightly increase towards higher growth voltage. The number of crystallites per unit area also follows similar trend as strain and dislocation density as deposition voltage changes. The reduction in the values of $N$ after annealing shows that the observed crystallite size growth on annealing, for most of the samples, must be as a result of recrystallisation and coalescence of small crystallites into large ones. The sample grown at cathodic voltage of $1445 \mathrm{mV}$ has the least strain, dislocation density, and number of crystallites per unit area both before and after annealing followed by that grown at $1450 \mathrm{mV}$.

\subsection{Electrical Characterisation Using Photoelectrochemical} (PEC) Cell Study. Photoelectrochemical cell principle is based on the formation of a solid (semiconductor)/liquid (electrolyte) Schottky barrier junction when the solid is brought in intimate contact with the appropriate electrolyte [26]. If the solid (semiconductor in this case) is photoactive, electrons are promoted to the conduction band of the solid by the incident photons and electric current is produced. If the material is not photoactive, this will not happen. The difference between the voltages measured under illumination and in dark condition gives the PEC signal. Large PEC signals indicate the formation of wide or healthy depletion region in the semiconductor as a result of moderate doping. Small PEC 


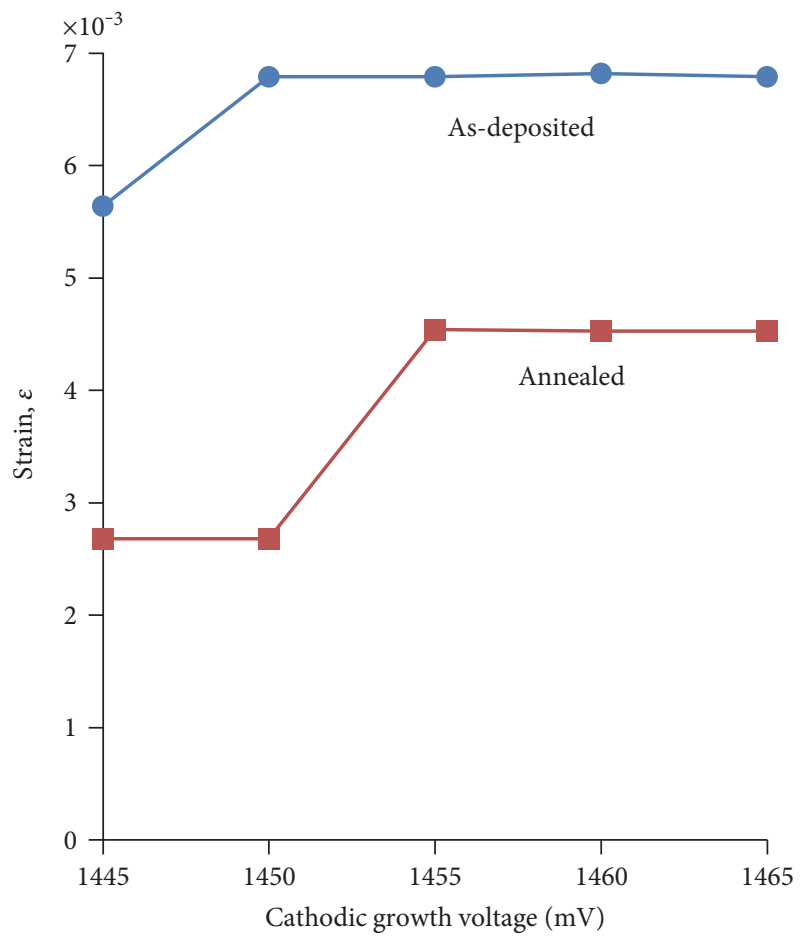

(a)

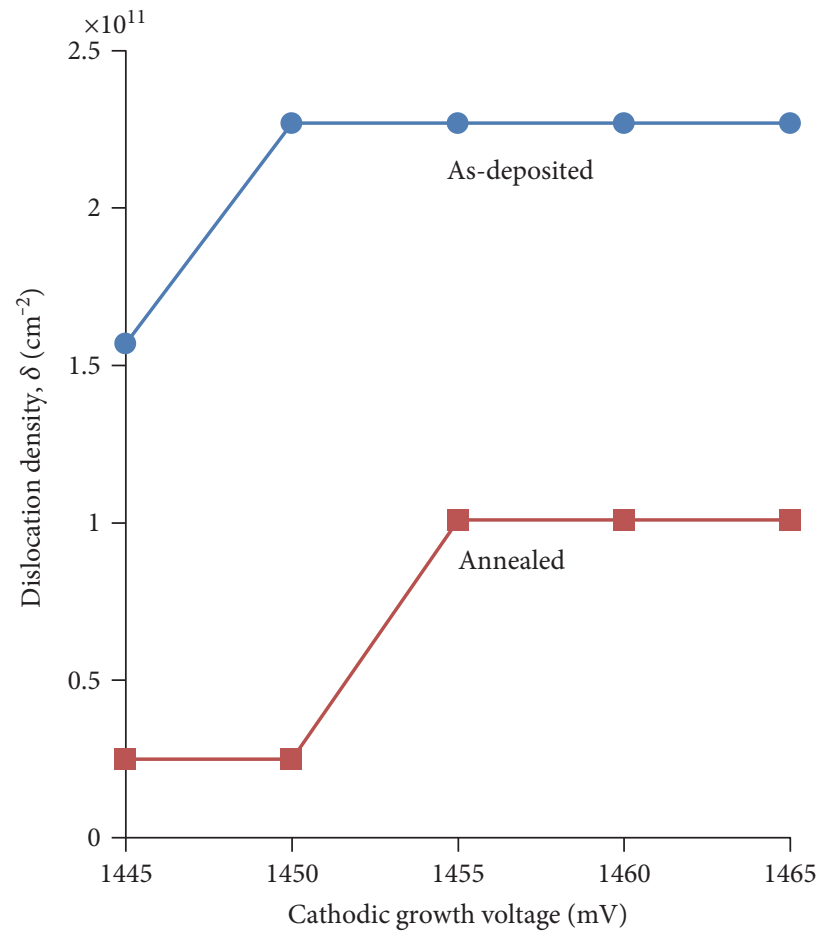

(b)

FIGURE 3: Variation of (a) internal strain and (b) dislocation density with growth voltage for the as-deposited and annealed CdS samples.

TABle 4: PEC signals of n-type as-deposited and annealed CdS layers grown at different cathodic voltages.

\begin{tabular}{lcc}
\hline$V_{\mathrm{g}}(\mathrm{mV})$ & $\begin{array}{c}\text { PEC signal }(\mathrm{mV}) \\
\text { (as-deposited) }\end{array}$ & $\begin{array}{c}\text { PEC signal }(\mathrm{mV}) \\
\text { (annealed) }\end{array}$ \\
\hline 1445 & -158 & -178 \\
1450 & -107 & -120 \\
1455 & -103 & -111 \\
1460 & -99 & -106 \\
1465 & -97 & -100 \\
\hline
\end{tabular}

signals indicate a heavily doped semiconductor with narrow depletion region. No PEC signal at all indicates an insulator, a conductor, or an intrinsic semiconductor. In the system used in the present study, which is calibrated using well-known n-type and p-type silicon, negative PEC signal indicates an n-type semiconductor while positive PEC signal indicates a p-type semiconductor as a result of different directions of band bending in each case.

The PEC results of the electrodeposited CdS layers under study are shown in Table 4. The PEC signals of all the samples have negative values before and after annealing indicating that the samples all have n-type electrical conductivity. This result is in perfect agreement with the fact that CdS occurs naturally as an n-type semiconductor. It is a difficult task to obtain intrinsic p-type doping of CdS. However, some researchers have achieved extrinsic p-doping of $\mathrm{CdS}$ by mainly using $\mathrm{Cu}$ as a dopant [35]. Bi has also been used to achieve p-type doping in $\mathrm{CdS}$ through ion implantation
[36]. It is important to mention that the physical appearance of these CdS samples was dark greenish yellow in the as-deposited form which is not the colour of pure CdS. This is due to the long period of growth ( 45 minutes) at the growth conditions used.

However, after annealing, the samples became yellowish or orange yellow which is the right colour of CdS. The dark as-deposited samples do not show good optical properties and end up producing $\mathrm{CdS} / \mathrm{CdTe}$ solar cells with very poor photovoltaic activity as a result of poor optoelectronic quality. For this reason and the fact that $\mathrm{CdS}$ is usually heat-treated before use in the fabrication of CdTe-based solar cell, the optical characterisation of the CdS samples under study in this work is based on the annealed samples only.

3.3. Optical Characterisation Using Spectrophotometry. Figures 4(a), 4(b), and 4(c), respectively, show the graphs of transmittance versus photon wavelength, absorbance $(A)$ versus photon wavelength, and square of absorbance $\left(A^{2}\right)$ versus photon energy for the annealed CdS samples grown at different cathodic voltages for 45 minutes. The three figures show that the five samples have similar transmittance and absorption spectra, indicating that CdS films of similar optical properties can be grown in the deposition voltage range under study. This supports the reproducibility and suitability of electrodeposition as a semiconductor growth technique.

The transmittance spectra have edges in the range 480$490 \mathrm{~nm}$ while the absorbance spectra have edges in the range $525-530 \mathrm{~nm}$, and the different layers display approximately the same energy bandgap of $\sim 2.42 \mathrm{eV}$ with similar absorption 


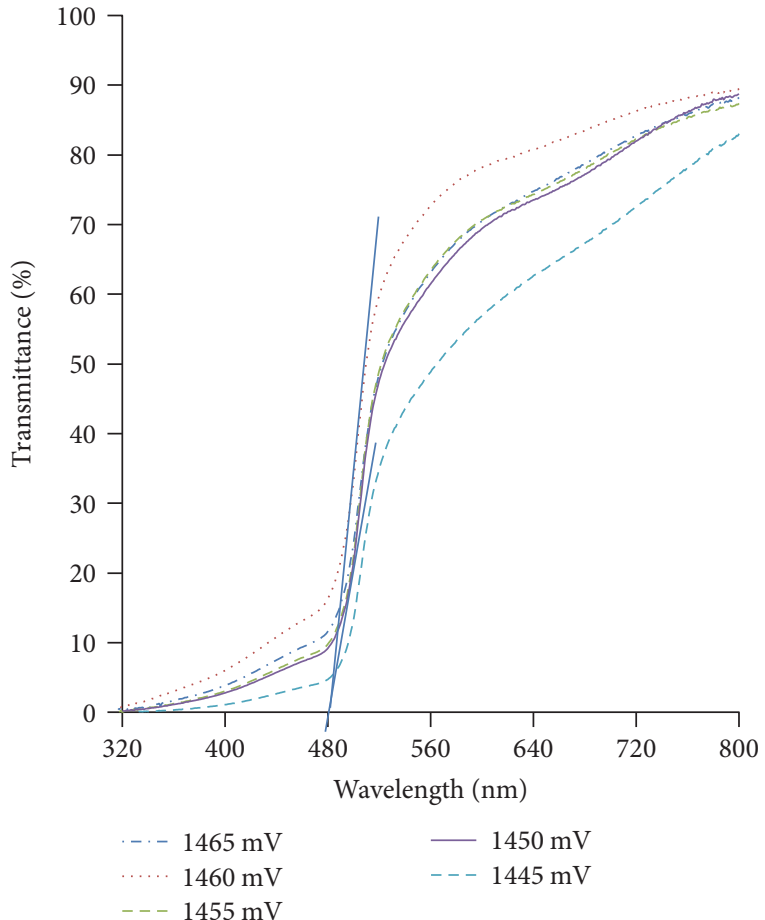

(a)

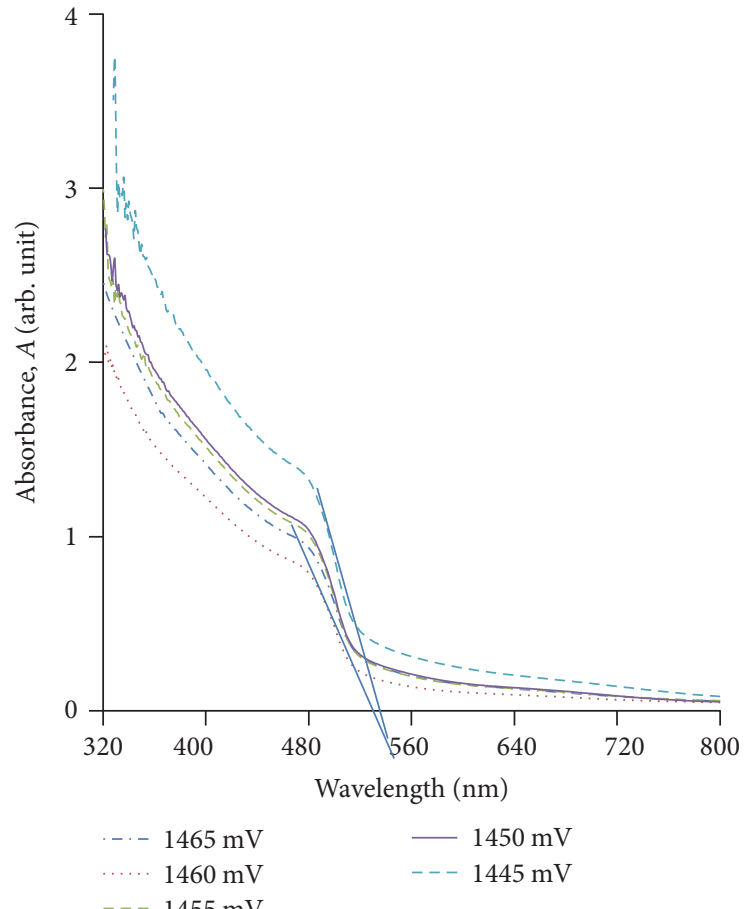

(b)

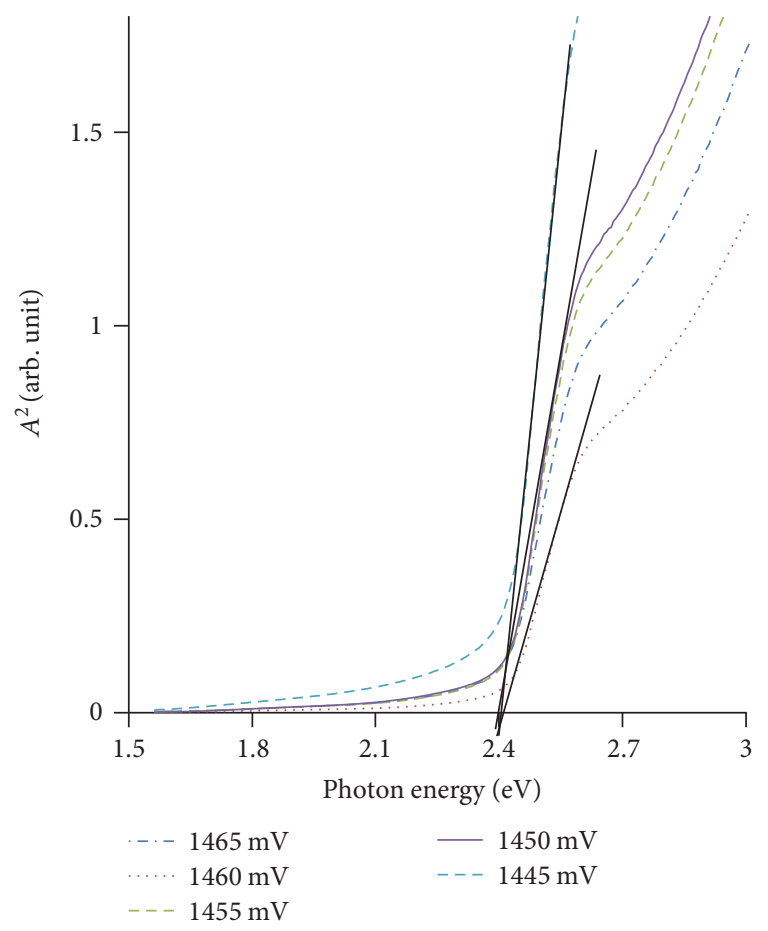

(c)

FIGURE 4: (a) Transmittance versus wavelength, (b) absorbance $(A)$ versus wavelength, and (c) $A^{2}$ versus photon energy for annealed CdS samples grown at different cathodic voltages for 45 minutes.

edges. These results show that CdS layers of similar optical quality can be deposited in this range of growth voltage. Figure 4(a) shows that the transmittance gets slightly weaker at lower deposition voltages in the higher wavelength range. From the wavelength of $512 \mathrm{~nm}$ corresponding to the energy bandgap to the wavelength of $800 \mathrm{~nm}$ in the near infrared, the samples have transmittance values in the range $28 \%$ $80 \%$ (for $1445 \mathrm{mV}$ ), $40 \%-88 \%$ (for $1450 \mathrm{mV}$ ), $45 \%-87 \%$ (for $1455 \mathrm{mV}$ ), $52 \%-89 \%$ for $(1460 \mathrm{mV}$ ), and $45 \%-88 \%$ (for $1465 \mathrm{mV}$ ). The sample grown at $1460 \mathrm{mV}$ has the best 

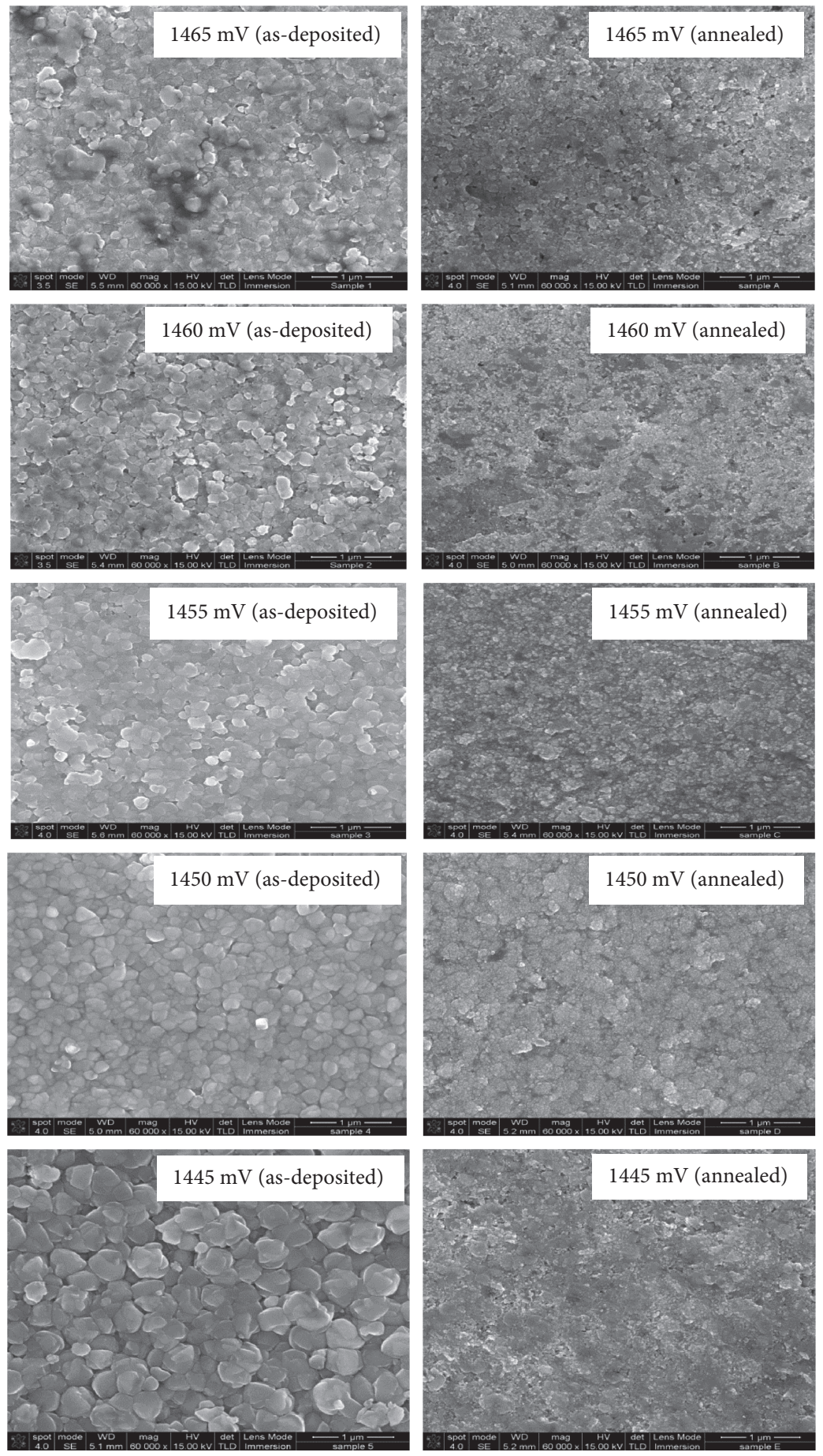

FiguRE 5: SEM images of as-deposited and annealed CdS samples grown at different cathodic voltages for 45 minutes. CdCl 2 treatment was done with saturated $\mathrm{CdCl}_{2}$ in methanol.

transmittance while that grown at $1445 \mathrm{mV}$ has the least transmittance. The absorption spectra (Figures 4 (b) and $4(\mathrm{c})$ ) follow an opposite trend with the $1445 \mathrm{mV}$ sample showing the best absorbance and the $1460 \mathrm{mV}$ sample showing the least absorbance. It is important to note that for application as window layer in solar cell fabrication, CdS with the highest possible transmittance (mostly in the visible region) is desirable.
3.4. Morphological Characterisation Using Scanning Electron Microscopy (SEM). Figure 5 shows the SEM images of asdeposited and annealed CdS samples grown for 45 minutes each at the five different cathodic voltages. The very first striking observation in the figures is the effect of postdeposition annealing (with $\mathrm{CdCl}_{2}$ treatment) on these samples. It is important to recall that these samples were treated with saturated $\mathrm{CdCl}_{2}$ solution in methanol before annealing at 

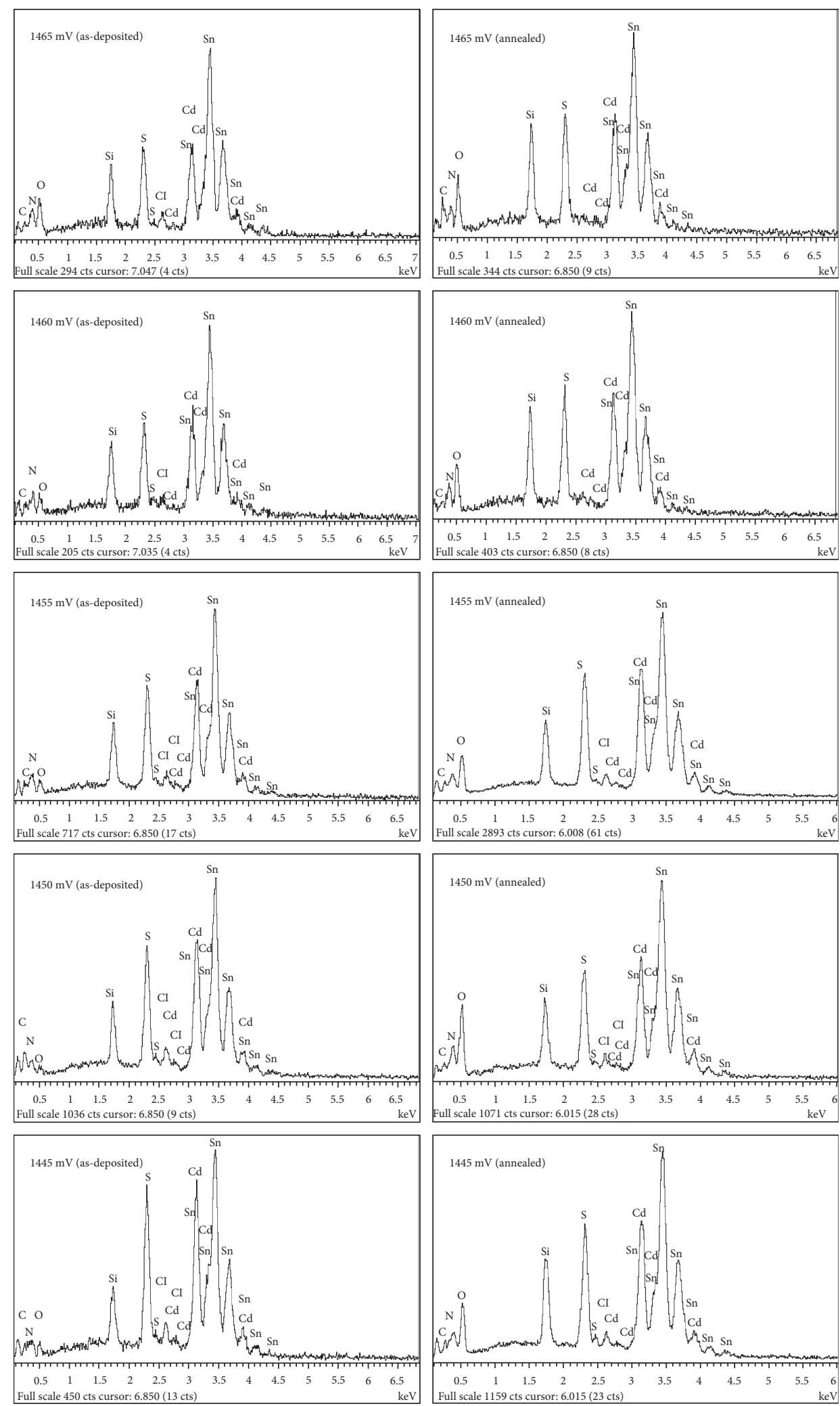

FIgURE 6: EDX spectra of as-deposited and annealed CdS samples grown at different cathodic voltages for 45 minutes. Annealing was preceded by $\mathrm{CdCl}_{2}$ treatment.

$400^{\circ} \mathrm{C}$ for 20 minutes in air. The "cementing" effect on the surface grains after annealing has not been observed in samples annealed without this treatment [37]. This cementing effect on the surface grains therefore appears to be as a result of treatment with excess $\mathrm{CdCl}_{2}$ in methanol since this effect is seen in samples grown at the different voltages explored. 
TABle 5: Percentage Cd and S atomic compositions of as-deposited and annealed CdS samples grown for 45 minutes at different cathodic voltages.

\begin{tabular}{|c|c|c|c|c|c|c|c|}
\hline \multirow{3}{*}{$\begin{array}{l}\text { Cathodic growth } \\
\text { voltage } \\
(\mathrm{mV})\end{array}$} & \multirow{3}{*}{$\begin{array}{l}\text { Growth time } \\
\qquad(\min )\end{array}$} & \multicolumn{4}{|c|}{ Atomic composition (\%) } & \multirow{3}{*}{$\begin{array}{l}\text { As-deposited } \\
\mathrm{Cd} / \mathrm{S}\end{array}$} & \multirow{3}{*}{$\begin{array}{c}\text { Annealed } \\
\mathrm{Cd} / \mathrm{S}\end{array}$} \\
\hline & & \multicolumn{2}{|c|}{ As-deposited } & \multicolumn{2}{|c|}{ Annealed } & & \\
\hline & & $\mathrm{Cd}$ & S & $\mathrm{Cd}$ & S & & \\
\hline 1445 & 45 & 46.6 & 53.4 & 46.7 & 53.3 & 0.87 & 0.88 \\
\hline 1450 & 45 & 46.6 & 53.4 & 47.8 & 52.2 & 0.87 & 0.92 \\
\hline 1455 & 45 & 46.6 & 53.4 & 47.8 & 52.2 & 0.87 & 0.92 \\
\hline 1460 & 45 & 45.1 & 54.9 & 45.7 & 54.3 & 0.82 & 0.84 \\
\hline 1465 & 45 & 42.1 & 57.9 & 44.2 & 55.8 & 0.73 & 0.79 \\
\hline
\end{tabular}

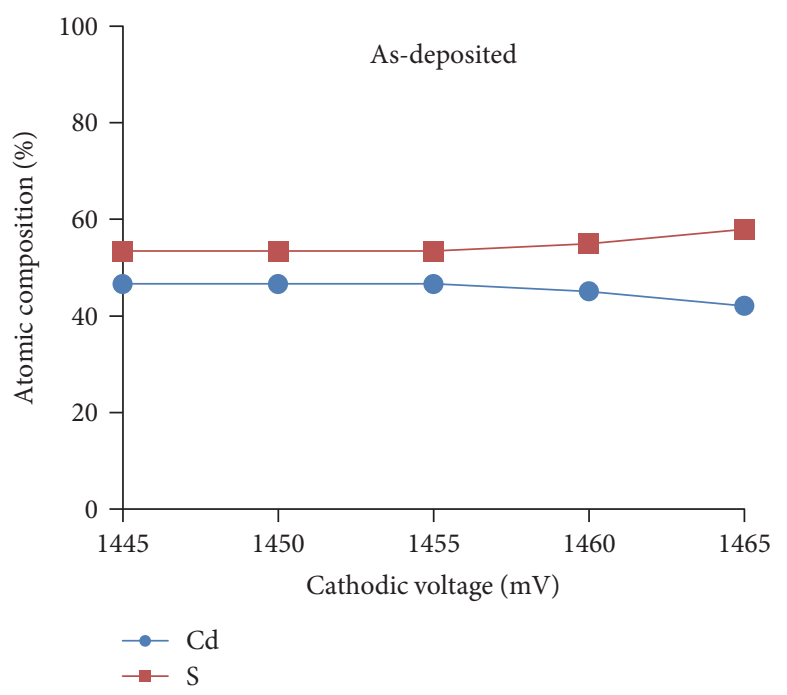

(a)

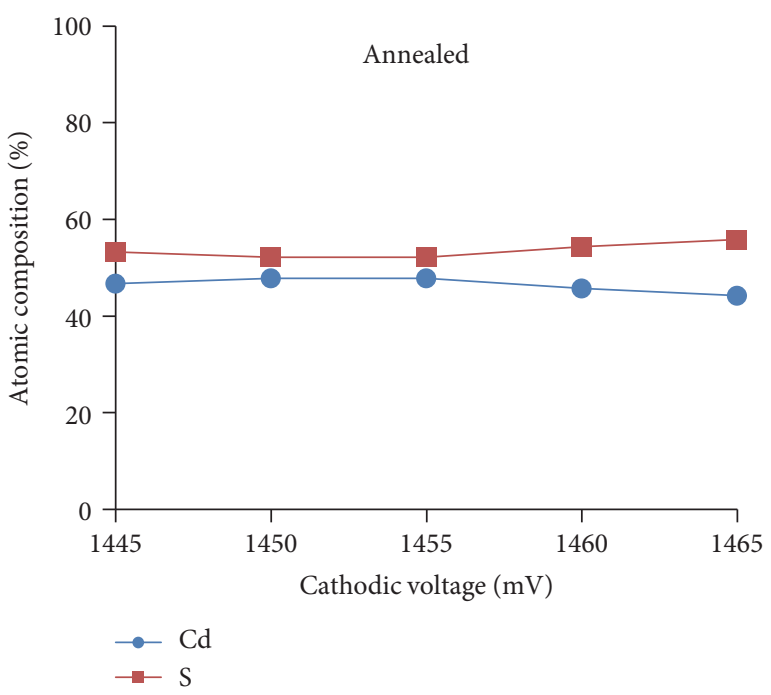

(b)

Figure 7: Percentage Cd and S atomic compositions of (a) as-deposited and (b) annealed CdS samples grown for 45 minutes at different cathodic voltages.

In the as-deposited samples, one notices that the grains are more clearly visible in the samples grown at lower cathodic voltages of $1445 \mathrm{mV}$ and $1450 \mathrm{mV}$. As the growth voltage increases, the tendency of the grains to fuse together increases as well. This therefore makes it difficult to estimate the grain sizes of these layers from the SEM images as is also the case in the annealed sample. The observation of clear grain sizes in the samples grown at cathodic voltages of $1445 \mathrm{mV}$ and $1450 \mathrm{mV}$ is in agreement with the XRD analysis of the crystallites in these materials. It can be recalled that the XRD analysis of Tables 1 and 2 shows that only the samples grown at these two voltages displayed higher increase in crystallite sizes after annealing. The crystallite size after annealing according to Table 2 was $63.02 \mathrm{~nm}$ for both $1445 \mathrm{mV}$ and $1450 \mathrm{mV}$. This is in agreement with the observed grain sizes of the as-deposited samples in Figure 5 with the sample grown at $1445 \mathrm{mV}$ showing larger grains than the sample grown at $1450 \mathrm{mV}$. This surface "cementing" effect may be viewed as an advantage when these films are used in fabricating CdS/CdTe solar cells as it will tend to fill the gaps between grains in CdS. These gaps, if not covered, could act as shunting paths when CdTe is deposited on CdS resulting in solar cells with poor open-circuit voltage and fill factor.

3.5. Compositional Characterisation Using Energy Dispersive $X$-Ray (EDX) Analysis. Figure 6 shows the EDX spectra of the five samples before and after postdeposition annealing indicating the presence of both $\mathrm{Cd}$ and $\mathrm{S}$ atoms in these materials.

The peaks showing $\mathrm{C}, \mathrm{N}, \mathrm{O}$, and Si must have come from the underlying glass/FTO substrate on which these CdS layers were grown. The percentage atomic concentrations of $\mathrm{Cd}$ and $\mathrm{S}$ in these samples, obtained from analysis of the EDX, are presented in Table 5 and Figure 7.

Both Table 5 and Figure 7(a) show that all the asdeposited CdS samples were S-rich. It is also observed in the as-deposited samples that the concentration of $S$ in the layers roughly increases as the growth voltage increases while the concentration of $\mathrm{Cd}$ roughly decreases accordingly.

After annealing, both Table 5 and Figure 7(b) reveal all samples to be clearly S-rich at all growth voltages. A very close observation also shows that the samples become more stoichiometric after annealing with a slight increase in $\mathrm{Cd}$ 
concentration and a corresponding decrease in S concentration. These results and others seen previously demonstrate also that the best electrodeposited CdS material from this experiment comes after postdeposition annealing. The samples with the best stoichiometry before and after annealing are the samples grown at the cathodic voltages of $1450 \mathrm{mV}$ and $1455 \mathrm{mV}$ with $\mathrm{Cd} / \mathrm{S}=0.92$ after annealing. All other samples have $\mathrm{Cd} / \mathrm{S}<0.92$ after annealing. It should be mentioned at this point though that EDX is not a very accurate technique for the precise determination of chemical composition. However, it is the only available technique within our reach at the time of this project. As a result, the compositional analysis results presented in this work are rather qualitative than quantitative.

\section{Conclusions}

Electrodeposition of CdS thin films at different cathodic growth voltages and characterisation of the films before and after postdeposition heat treatment have been presented. The electrodeposition of these layers was carried out using two-electrode system for process simplification and cost reduction. PEC results show that all the deposited samples have n-type electrical conductivity over the range of cathodic deposition voltages of $1445-1465 \mathrm{mV}$ considered. XRD results show that as-deposited samples were polycrystalline in nature with mixed cubic and hexagonal CdS phases. After annealing however, the XRD peaks representing cubic phase disappear completely while the peaks of the hexagonal phase are enhanced with preferred orientation in the (002) plane. Further analysis of the structural properties shows that crystallites of the electrodeposited CdS samples are strained with internal strain values in the range $5.64 \times 10^{-3}-6.82 \times 10^{-3}$ which reduced to $2.68 \times 10^{-3}-4.54 \times 10^{-3}$ after annealing with prior $\mathrm{CdCl}_{2}$ treatment. The number of dislocation lines per unit area is found to be in the range $1.57 \times 10^{11}-2.27 \times 10^{11} \mathrm{~cm}^{-2}$ and reduced to $0.25 \times 10^{11}-1.01 \times 10^{11} \mathrm{~cm}^{-2}$ after annealing. The number of crystallites per unit area is found to reduce from $3.2 \times 10^{12}-5.6 \times 10^{12} \mathrm{~cm}^{-2}$ for as-deposited samples to $0.2 \times 10^{12}-1.6 \times 10^{12} \mathrm{~cm}^{-2}$ after annealing, indicating increase in crystallite sizes after annealing. Crystallite sizes of the asdeposited films were in the range $21-25 \mathrm{~nm}$ which increased to $31-63 \mathrm{~nm}$ after annealing. The result of optical characterisation shows that the transmittance gets slightly weaker at lower deposition voltages while absorbance follows the opposite trend. The energy bandgap of all the annealed CdS films comes to $2.42 \mathrm{eV}$. SEM reveals that $\mathrm{CdCl}_{2}$ treatment, with saturated $\mathrm{CdCl}_{2}$ solution in methanol, results in cementing together of the surface grains after annealing thus modifying the surfaces of the films. EDX analysis shows that the electrodeposited CdS films are S-rich under the conditions used. The overall result suggests the best cathodic growth voltage to be in the range $1445-1450 \mathrm{mV}$.

\section{Conflicts of Interest}

The authors declare that there is no conflict of interest regarding the publication of this paper.

\section{Acknowledgments}

The principal author wishes to thank the Federal University of Technology, Owerri, Nigeria, and University of the Free State, South Africa, for financial support.

\section{References}

[1] F. Lisco, P. M. Kaminski, A. Abbas et al., "High rate deposition of thin film cadmium sulphide by pulsed direct current magnetron sputtering," Thin Solid Films, vol. 574, pp. 43-51, 2015.

[2] A. A. Ojo and I. M. Dharmadasa, " $15.3 \%$ efficient graded bandgap solar cells fabricated using electroplated CdS and CdTe thin films," Solar Energy, vol. 136, pp. 10-14, 2016.

[3] W. K. Metzger, "The potential and device physics of interdigitated thin film solar cells," Journal of Applied Physics, vol. 103, no. 9, article 094515, 2008.

[4] X. Wang, X. He, H. Zhu et al., "Subatomic deformation driven by vertical piezoelectricity from CdS ultrathin films," Science Advances, vol. 2, no. 7, article e1600209, 2016.

[5] Y. Kraftmankher, "Experiments on photoconductivity," European Journal of Physics, vol. 33, pp. 503-511, 2012.

[6] R. M. Ma, L. Dai, and G. G. Qin, "High-performance nanoSchottky diodes and nano-MESFETs made on single CdS nanobelts," Nano Letters, vol. 7, no. 4, pp. 868-873, 2007.

[7] T. Gaewdang and N. Wongcharoen, "Heterojunction properties of $\mathrm{p}-\mathrm{CuO} / \mathrm{n}-\mathrm{CdS}$ diode," Advanced Materials Research, vol. 1098, pp. 1-5, 2015.

[8] J. S. Meth, S. G. Zane, and G. Nunes Jr., "Dual insulated-gate field-effect transistors with cadmium sulfide active layer and a laminated polymer dielectric," Applied Physics Letters, vol. 84, no. 15, pp. 2922-2924, 2004.

[9] S. T. Navale, A. T. Mane, M. A. Chougule, N. M. Shinde, J. H. Kim, and V. B. Patil, "Highly selective and sensitive CdS thin film sensors for detection of $\mathrm{NO}_{2}$ gas," RSC Advances, vol. 4, pp. 44547-44554, 2014.

[10] I. A. Kirovskaya, O. T. Timoshenko, and E. O. Karpova, "The catalytic and photocatalytic properties of InP-CdS and ZnTe-CdS system components," Russian Journal of Physical Chemistry A, vol. 85, no. 4, pp. 557-560, 2011.

[11] K. Deng and L. Li, "CdS nanoscale photodetectors," Advanced Materials, vol. 26, no. 17, pp. 2619-2635, 2014.

[12] A. Bosio, N. Romeo, S. Mazzamuto, and V. Canevari, "Polycrystalline CdTe thin films for photovoltaic applications," Progress in Crystal Growth and Characterization of Materials, vol. 52, no. 4, pp. 247-279, 2006.

[13] M. Kim, A. Ochirbat, and H. J. Lee, "CuS/CdS quantum dot composite sensitizer and its applications to various $\mathrm{TiO} 2$ mesoporous film-based solar cell devices," Langmuir, vol. 31, no. 27, pp. 7609-7615, 2015.

[14] N. Naghavi, G. Renou, V. Bockelee et al., "Chemical deposition methods for cd-free buffer layers in $\mathrm{CI}(\mathrm{G}) \mathrm{S}$ solar cells: role of window layers," Thin Solid Films, vol. 519, no. 21, pp. 76007605, 2011.

[15] Z. Lu, R. Jin, Y. Liu et al., "Optimization of chemical bath deposited cadmium sulfide buffer layer for high-efficient CIGS thin film solar cells," Materials Letters, vol. 204, pp. 53-56, 2017.

[16] X. Shen, A. Yuan, F. Wang, J. Hong, and Z. Xu, "Fabrication of well-aligned CdS nanotube by CVD-template method," Solid State Communications, vol. 133, no. 1, pp. 19-22, 2005. 
[17] A. Kerimova, E. Bagiyev, E. Aliyeva, and A. Bayramov, "Nanostructured CdS thin films deposited by spray pyrolysis method," Physica Status Solidi C, vol. 14, no. 6, article 1600144, pp. 1-3, 2017.

[18] N. R. Paudel, K. A. Wieland, and A. D. Compaan, "Ultrathin CdS/CdTe solar cells by sputtering," Solar Energy Materials and Solar Cells, vol. 105, pp. 109-112, 2012.

[19] P. J. Sebastian and M. E. Calixto, "Porous CdS:CdO composite structure formed by screen printing and sintering of CdS in air," Thin Solid Films, vol. 360, no. 1-2, pp. 128-132, 2000.

[20] A. A. Ziabari and F. E. Ghodsi, "Growth, characterization and studying of sol-gel derived CdS nanocrystalline thin films incorporated in polyethyleneglycol: effect of post-growth heat treatment," Solar Energy Materials and Solar Cells, vol. 105, pp. 249-262, 2012.

[21] J. Schaffner, E. Feldmeier, A. Swirschuk, H. J. Schimper, A. Klein, and W. Jaegermann, "Influence of substrate temperature, growth rate and TCO substrate on the properties of CSS-deposited CdS thin films," Thin Solid Films, vol. 519, no. 21, pp. 7556-7559, 2011.

[22] D. G. Diso, G. E. A. Muftah, V. Patel, and I. M. Dharmadasa, "Growth of CdS layers to develop all-electrodeposited CdS/ CdTe thin film solar cells," Journal of Electrochemical Society, vol. 157, no. 6, pp. H647-H651, 2010.

[23] M. Rami, E. Benamar, M. Fahoume, F. Chraibi, and A. Ennaoui, "Effect of heat treatment with $\mathrm{CdCl}_{2}$ on the electrodeposited CdTe/CdS heterojunction," Moroccan Journal of Condensed Matter, vol. 3, no. 1, pp. 66-70, 2000.

[24] A. N. Abdul-Manaf, A. R. Weerasinghe, O. K. Echendu, and I. M. Dharmadasa, "Electro-plating and characterisation of cadmium sulphide thin films using ammonium thiosulfate as the sulfur source," Journal of Materials Science: Materials in Electronics, vol. 26, no. 4, pp. 2418-2429, 2015.

[25] O. K. Echendu and I. M. Dharmadasa, "Graded-bandgap solar cells using all-electrodeposited ZnS, CdS and CdTe thin-films," Energies, vol. 8, no. 5, pp. 4416-4435, 2015.

[26] O. K. Echendu, A. R. Weerasinghe, D. G. Diso, F. Fauzi, and I. M. Dharmadasa, "Characterization of $n$-type and $p$-type $\mathrm{ZnS}$ thin layers grown by electrochemical method," Journal of Electronic Materials, vol. 42, pp. 692-700, 2013.

[27] O. K. Echendu, F. Fauzi, A. R. Weerasinghe, and I. M. Dharmadasa, "High short-circuit current density CdTe solar cells using all-electrodeposited semiconductors," Thin Solid Films, vol. 556, pp. 529-534, 2014.

[28] A. A. Ojo and I. M. Dharmadasa, "Optimisation of $\mathrm{pH}$ of cadmium chloride post-growth-treatment in processing CdS/ CdTe based thin film solar cells," Journal of Materials Science: Materials in Electronics, vol. 28, no. 10, pp. 7231-7242, 2017.

[29] M. Miyake, K. Murase, T. Hirato, and Y. Awakura, "Hall effect measurements on CdTe layers electrodeposited from acidic aqueous electrolyte," Journal of Electroanalytical Chemistry, vol. 562, no. 2, pp. 247-253, 2004.

[30] G. Sasikala, R. Dhanasekara, and C. Subramanian, "Electrodeposition and optical characterization of CdS thin films on ITO-coated glass," Thin Solid Films, vol. 302, pp. 71-76, 1997.

[31] O. I. Olusola, O. K. Echendu, and I. M. Dharmadasa, "Development of CdSe thin films for application in electronic devices," Journal of Materials Science: Materials in Electronics, vol. 26, no. 2, pp. 1066-1076, 2015.

[32] S. Chander and M. S. Dhaka, "Preparation and physical characterization of CdTe thin films deposited by vacuum evaporation for photovoltaic applications," Advanced Materials Letters, vol. 6, no. 10, pp. 907-912, 2015.

[33] S. Chander and M. S. Dhaka, "Optimization of physical properties of vacuum evaporated CdTe thin films with the application of thermal treatment for solar cells," Materials Science in Semiconductor Processing, vol. 40, pp. 708-712, 2015.

[34] H. Metin, S. Erat, F. M. Emen et al., "Thermoluminescence properties of CdS films under nitrogen atmosphere," Journal of Luminescence, vol. 130, no. 8, pp. 1531-1538, 2010.

[35] R. Xie, J. Su, M. Li, and L. Guo, "Structural and photoelectrochemical properties of $\mathrm{Cu}$-doped $\mathrm{CdS}$ thin films prepared by ultrasonic spray pyrolysis," International Journal of Photoenergy, vol. 2013, Article ID 620134, 7 pages, 2013.

[36] F. Chernow, G. Eldridge, G. Ruse, and L. Wahlin, "High conductivity p-type CdS," Applied Physics Letters, vol. 12, no. 10, pp. 339-341, 1968.

[37] O. K. Echendu, Thin Film Solar Cells Using AllElectrodeposited ZnS, CdS and CdTe Materials, Doctoral Thesis, Sheffield Hallam University, United Kingdom, 2014. 

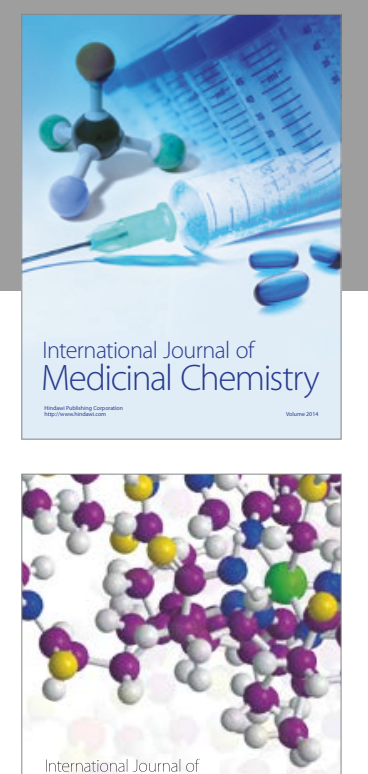

Carbohydrate Chemistry

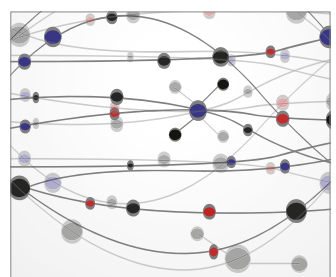

The Scientific World Journal
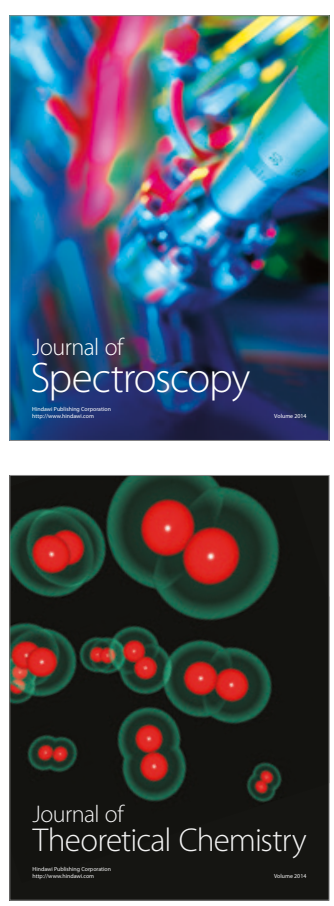
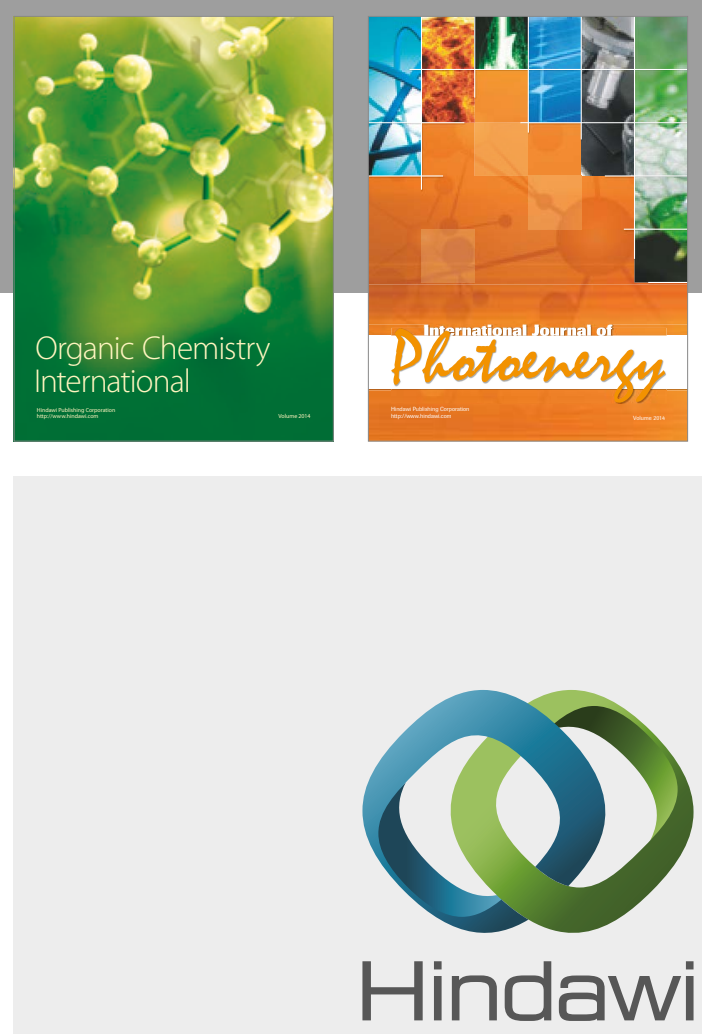

Submit your manuscripts at

https://www.hindawi.com

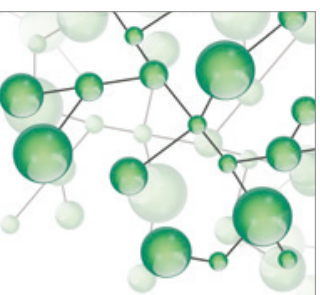

International Journal of

Inorganic Chemistry

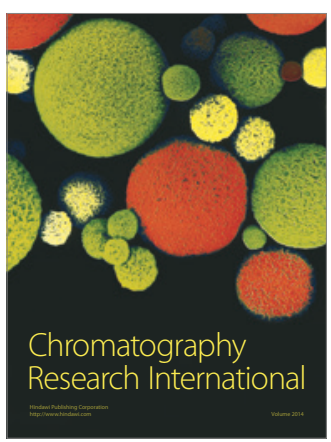

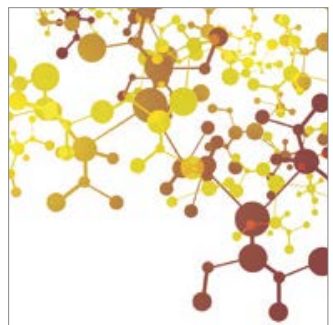

Applied Chemistry
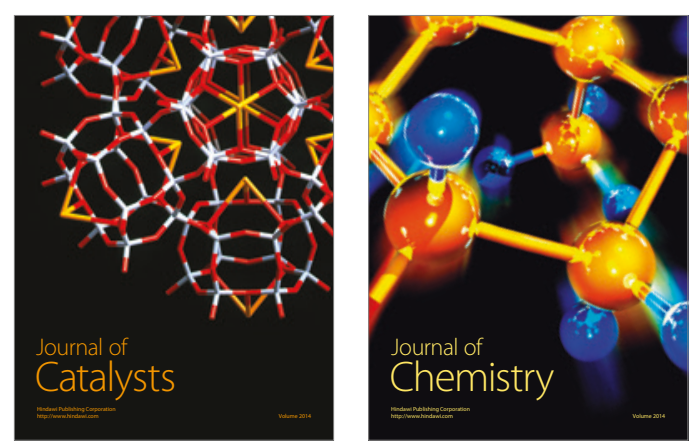
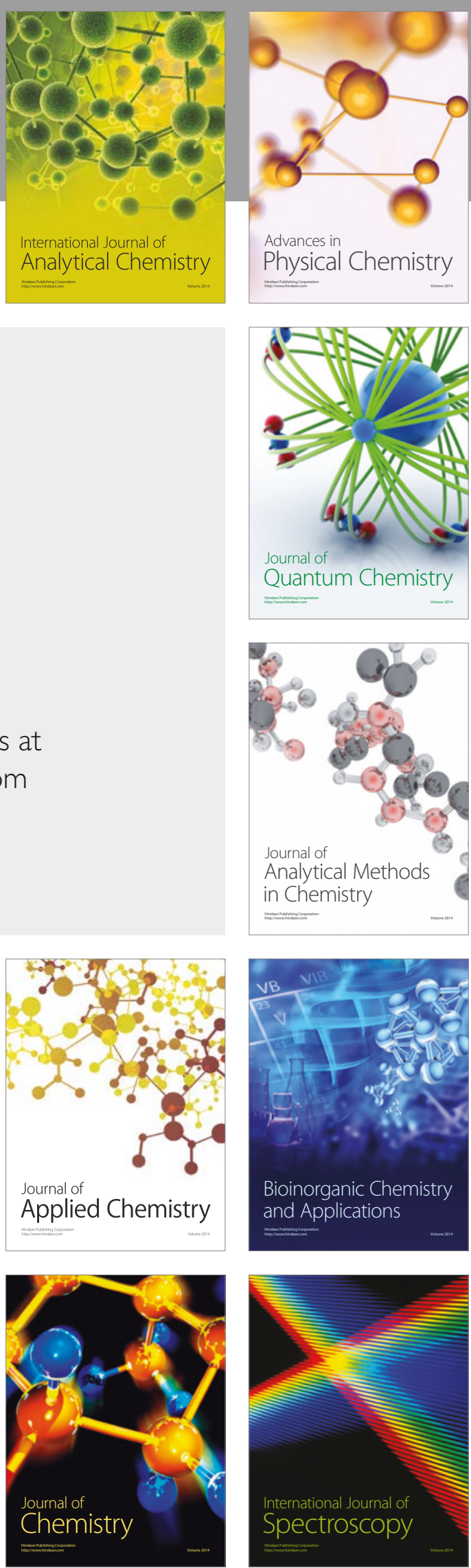